\title{
PENGARUH PENGGUNAAN MEDIA PERMAINAN KARTU KUARTET TERHADAP MINAT BELAJAR IPS SISWA SEKOLAH DASAR
}

\author{
NURFAIZAH AP, ABDUL RAHMAN, AMALIYAH RAMADHANI \\ Universitas Negeri Makassar \\ Email: nurfaizah.ap@unm.ac.id
}

\begin{abstract}
ABSTRAK
Penelitian ini bertujuan untuk mengetahui pengaruh penggunaan media permainan kartu kuartet terhadap minat belajar siswa pada mata pelajaran IPS. Jenis penelitian adalah quasi eksprimen . Desain penelitian ini adalah true eksprimentasl design. Sampel penelitian ini adalah sebanyak 2 kelas, kelas IV A sebagai kelas eksprimen dengan jumlah siswa 27 orang dan Kelas IV B sebagai kelas kontrol dengan jumlah siswa 26 orang. Teknik pengumpulan data yaitu lembar observasi, angket dan dokumentasi. Teknik analisis data yang digunakan yaitu analisis statistik deskriptif dan analisis statistik inferesial yang terdiri dari uji normalitas, uji homegenitas, dan uji hipotesis menggunakan independent sample t-test. Hasil penelitian yang telah dilakukan dapat disimpulkan bahwa: (1) Gambaran penggunaan media permainan kartu kuartet masuk kedalam kategori sangat baik. Hal ini dapat dilihat dari keterlaksanaan media permainan kartu kuartet selama 2 kali pertemuan dengan kaetgori sangat baik. (2) Minat belajar IPS siswa yang diperoleh pada angket kelas eksprimen masuk ke dalam kategori sangat berminat, dan angket pada kelas kontrol masuk ke dalam kategori berminat. (3) Terdapat pengaruh yang signifikan penggunaan media permainan kartu kuartet terhadap minat belajar IPS siswa kelas IV SDN 17 Langnga-Langnga.
\end{abstract}

Kata Kunci: Media permainan kartu kuartet, minat belajar, IPS.

\section{ABSTRACT}

This study aims to determine the effect of using quartet card game media on students' interest in learning in social studies subjects. This type of research is quasi experimental research. The design of this research is a true experimental design. The samples of this study were 2 classes, class IV A as the experimental class with 27 students and Class IV B as the control class with 26 students. Data collection techniques are observation sheets, questionnaires and documentation. The data analysis technique used is descriptive statistical analysis and inferential statistical analysis consisting of normality test, homogeneity test, and hypothesis testing using independent sample t-test. The results of the research that have been carried out can be concluded that: (1) The description of the use of the quartet card game media is in the very good category. This can be seen from the implementation of the quartet card game media for 2 meetings with very good categories. (2) Students' interest in social studies learning obtained in the experimental class questionnaire is in the very interested category, and the control class questionnaire is in the interested category. (3) There is a significant effect of using quartet card game media on interest in social studies learning for fourth graders at SDN 17 Langnga-Langnga.

Keywords: Quartet card game media, interest in learning, Social Studies.

\section{PENDAHULUAN}

Keberhasilan suatu proses pembelajaran ditentukan oleh adanya minat atau ketertarikan siswa dalam mempelajari suatu mata pelajaran. Susanto (2016) mengatakan bahwa minat adalah dorongan dalam diri seseorang yang dapat menimbulkan ketertarikan atau perhatian yang menyebabkan dipilihnya suatu kegiatan yang menguntungkan, mnyenangkan dan lamakelamaan akan menimbulkan kepuasaan dalam dirinya. Oleh karena itu guru harus membuat suasana pembelajaran lebih menyenangkan dan lebih aktif dengan menggunakan media sehingga peserta didik lebih tertarik dalam kegiatan pembelajaran. 
Hal ini sejalan dengan pemendikbud No. 22 Tahun 2006 Tentang Standar Proses Pendidikan Dasar Menegah yang berbunti proses pembelajaran pada satuan pendidikan diselenggarakan secara interaktif, inspiratif, menyenangkan, menantang, memotivasi peserta diidk untuk berparitisipasi aktif, serta memberikan ruang yang cukup bagi prakarsa, kreativitas, dan kemandirian sesuai dengan bakat, minat, dan perkembangan fisik serta psikologis peserta didik. Jadi, guru harus selalau berfikir kreatif dan inovatif agar dapat membantu memabngun minatnya dengan memberikan media-media pembelajaran yang menarik sehingga siswa tidak merasa bosan selama proses pembelajaran berlangsung.

Namun Selama ini masih ada guru yang menyampaikan materi hanya dengan menggunakan metode ceramah saja, dan pada umumnya tidak menggunakan alat peraga atau media sehingga siswa menjadi bosan dan bahkan kurang mampu memahami dan menguasai materi IPS yang sifatnya abstrak.. Berdasarkan hasil observasi di kelas IV SDN 17 LangngaLangnga Kabupaten Pangkajene dan Kepulauan teramati bahwa kurangnya perhatian dan minat siswa dalam pembelajaran IPS sehingga pembelajaran tidak dapat berjalan secara maksimal. Sesuai dengan kenyataan di atas tentang kurangnya minat belajar siswa pada pembelajaran IPS, maka perlu adanya pemecahan masalah yaitu dengan menggunakan media kartu kuartet dalam bentuk permainan. Pemilihan penggunaan media ini karena dalam proses pembelajaran, anak belajar sambil bermain sehingga anak akan belajar sesuai dengan tuntutan perkembangannya. Pemilihan media ini juga berupaya untuk menyeimbangkan otak kanan dan otak kiri yaitu pemahaman konsep dan menumbuhkan kreativitas siswa, agar siswa dapat mengembangkan pengetahuan, berinteraksi dengan teman, kemudian perkembangan sosial, emosional, fisik dan motorik, bahasa dan kognisinya juga dapat berkembang dengan baik..

Permainan media kartu kuartet atau bisa disebut juga dengan kartu bergambar merupakan salah satu permainan yang dapat digunakan dalam pembelajaran. Selain menyenangkan, permainan ini juga tidak asing kebedarannya bagi siswa, materi dalam kartu bergambar ini disajikan dalam bentuk gambar yang dilengkapi dengan keterangan dari gambar tersebut, sehingga mempunyai daya tarik tersendiri bagi siswa untuk mempelajarinya.

Menurut Sumargono et al., (2019, h. 245) "kartu kuartet adalah sejenis permainan yang terdiri atas beberapa jumlah kartu bergambar yang telah tertera keterangan berupa tulisan yang menerangkan gambar tersebut". Sedangkan menurut Rohmat (2006) "kartu kuartet adalah kartu yang memiliki kemiripan denga kartu remi karena di dalam kartu terdiri atas empat kartu sepadan, namun pada kartu kuartet memiliki jumlah kartu yang dapat disesuaikan dengan kebutuhan peneliti"(Widagdo, 2020, h. 184-185) .Sekamelang (2006) menjelaskan "bahwa kartu kuartet adalah sejenis permainan yang terdiri atas beberapa jumlah kartu bergambar yang dari kartu bergambar tersebut tertera keterangan berupa tulisan yang menerangkan gambar tersebut" (Hidayat , 2015, h. 9). Kartu kuartet lebih dikenal sebagai suatu bentuk permainan kartu yang dimainkan oleh dua sampai empat orang pemain, dan sangat populer dikalangan anak-anak. Gambarnya pun bermacam-macam mulai dari gambar kartun, superstar, hewan, bintang film, dan juga dapat dalam bentuk pengetahuan. Media tersebut diharapkan dapat menarik minat dan perhatian siswa untuk belajar IPS.

Menurut (Berutu dan Tambunan, 2018, h.111) "minat adalah rasa suka dan ketertarikan pada suatu hal atau aktifitas tanpa ada yang menyuruh".Sejalan dengan pendapat tersebut, Slameto (Khodijah dan Setiawan, 2020) mengatakan bahwa minat adalah rasa suka dan tertarik terhadap sesuatu atau kegiatan lain berdasarkan kesadaran dari dalam diri sendiri. Selain itu, menurut Sirait (2016) minat adalah kecenderungan rasa suka yang tinggi yang terdiri dari perasaan senang, memperhatikan, kesungguhan, adanya motif dan tujuan dalam mencapai suatu tujuan.

Hendra (2017) menyatakan tanpa adanya minat dalam diri siswa terhadap hal yang akan dipelajari, maka siswa akan bosan untuk belajar sehingga hasil belajar akan kurang optimal atau bahkan tidak seperti yang diharapkan. Hal ini berarti bahwa belajar merupakan salah satu aktivitas yang tidak dapat dipisahkan dari minat. Berdasarkan uraian tersebut di atas maka peneliti tertarik untuk melakukan suatu Penelitian tentang Pengaruh Penggunaan Media 
Permainan Kartu Kuartet Terhadap Minat Belajar IPS Siswa Sekolah Dasar. Penelitian ini bertujuan untuk mengetahui pengaruh penggunaan media permainan kartu kuartet terhadap minat belajar siswa pada mata pelajaran IPS dengan rumusan masalah sebagai berikut; (1) Bagaimanakah gambaran penggunaan media permainan kartu kuartet pada mata pelajaran IPS siswa kelas IV SDN 17 Langnga-Langnga Kabupaten Pangkajene dan Kepulauan?; (2) Bagaimana gambar minat belajar IPS siswa setelah menggunakan media permainan kartu kuartet di kelas IV SDN 17 Langnga-Langnga Kabupaten Pangkajene dan Kepulauan?; (3) Apakah ada pengaruh penggunaan media permainan kartu kuartet terhadap minat belajar IPS siswa kelas IV SDN 17 Langnga-Langnga Kabupaten Pangkajene dan Kepulauan?.

\section{METODE PENELITIAN}

Pendekatan yang digunakan dalam penelitian ini adalah kuantitatif yang bersifat deskriptif. Jenis penelitian adalah quasi eksperimen. Penelitian ini dilaksanakan pada semester ganjil 7 Juni-02 Juli 2021 di SDN 17 Langnga-Langnga Kabupaten Pangkajene dan Kepulauan. Sampel penelitian adalah kelas IV A sebagai kelas eksprimen dengan jumlah siswa 27 orang dan Kelas IV B sebagai kelas kontrol dengan jumlah siswa 26 orang. Desain penelitian ini menggunakan True-Eksprimental Design dengan bentuk Pretest-Posttest Control Group Design yang dapat digambarkan sebagai berikut:

Tabel 1. Rancangan Desain Penelitian

\begin{tabular}{ccc}
\hline Pre non-test & Treatment & Post non-test \\
\hline $\mathrm{O}_{1}$ & $\mathrm{~T}$ & $\mathrm{O}_{3}$ \\
\hline $\mathrm{O}_{2}$ & $\mathrm{X}$ & $\mathrm{O}_{4}$ \\
\hline
\end{tabular}

Sumber:Sugiyono, 2016

Keterangan:

$\mathrm{O}_{1}=$ Pre non-test Kelompok Eksperimen (Angket minat siswa sebelum pembelajaran menggunakan media pembelajaran permainan kartu kuartet pada kelompok eksperimen)

$\mathrm{O}_{2}=$ Pre non-testKelompok Kontrol (Angket minat siswa sebelum pembelajaran tidak menggunakan media pembelajaran permainan kartu kuartet)

$\mathrm{O}_{3}=$ Post non-test Kelompok Eksperimen (Angket minat siswa setelah pembelajaran menggunakan media pembelajaran permainan kartu kuartet pada kelompok eksperimen)

$\mathrm{O}_{4}=$ Post non-testKelompok Kontrol (Angket minat siswa setelah pembelajaran tidak menggunakan media pembelajaran permainan kartu kuartet

Teknik pengumpulan data yaitu lembar observasi, dan angket. Lembar observasi sebagai instrumen untuk melihat dan mengamati keterlaksaan media permainan kartu kuartet . Angket dalam bentuk skala Likert merupakan instrumen yang digunakan untuk mengukur minat belajar siswa. Data yang telah diperoleh dianalisis dengan menggunakan analisis statistik, yaitu statistik deskriptif dan statistik inferensial.Analisis statistik deskriptif digunakan untuk mendeskripsikan minat siswa dalam pembelajaran IPS. Adapun distribusi kategori minat siswa ketika menggunakan media pembelajaran permainan kartu kuartet pada proses pembelajaran dapat dilihat pada rumus:

$$
i=\frac{\text { skor terting gi-skor terendah }}{\text { jumlah kategori }}
$$

Kategori minat siswa ketika menggunakan media pembelajaran permainan kartu kuartet pada proses pembelajaran dapat dilihat pada tabel berikut: 
Vol. 1 No. 3 Desember 2021, e-ISSN : 2797-8842 | p-ISSN : 2797-9431

Tabel 2 Kategori Minat Belajar Siswa

\begin{tabular}{ccc} 
No & Interval & Kategori \\
\hline 1 & $97,5<\mathrm{x} \leq 120$ & Sangat berminat \\
\hline 2 & $75<\mathrm{x} \leq 97,5$ & Berminat \\
\hline 3 & $52,5<\mathrm{x} \leq 75$ & Kurang berminat \\
\hline 4 & $30 \leq \mathrm{x} \leq 52,5$ & Tidak berminat \\
\hline
\end{tabular}

Sumber: Bundu, 2016

Pada penelitian ini digunakan pula statistik parametris yaitu Independent Sampel t-test untuk menguji ada tidaknya perbedaan signifikan antara dua variance/kelompok yang berbeda.Namun, sebelum melakukan pengujian hipotesis, terlebih dahulu dilakukan uji prasyarat yaitu uji normalitas data dan Uji homogenitas. Pengujian hipotesis pada penelitian ini menggunakan Independent Sample t-Test. Kriteria pengujian jika nilai probabilitas lebih besar dari taraf nyata 0,05 maka Ho diterima dan Ha ditolak.

Adapun hipotesis statistik dalam penelitian ini dapat dirumuskan sebagai berikut:

Ho: $\mu_{1}=\mu_{2}$

Ha: $\mu_{1} \neq \mu_{2}$

Keterangan:

Ho = Hipotesis awal

$\mathrm{Ha}=$ Hipotesis alternatif

$\mu_{1}=$ Rata-rata kelompok sebelum perlakuan

$\mu_{2}=$ Rata-rata kelompok setelah perlakuan

\section{HASIL DAN PEMBAHASAN}

\section{Hasil Penelitian}

Penelitian dilakukan selama 2 minggu dengan 4 kali pertemuan baik di kelas eksprimen maupun di kelas kontrol. Pada pertemuan pertama kedua kelas tersebut diberikan pre non-test (tes awal), selanjutnya dilakukan pembelajaran selama 2 kali pertemuan. Pada kelas eksprimen menggunakan media permainan kartu kuartet sedangkan kelas kontrol tidak menggunakan media permainan kartu kuartet. pertemuan terakhir pada kedua kelas tersebut diberikan post non-test untuk mengetahui apakah ada perbedaan minat belajar pada kedua kelas tersebut.

a. Gambaran penggunaan media permainan kartu kuartet terhadap minat belajar IPS

Pelaksanaan proses pembelajaran IPS di kelas eksprimen dengan materi keberagaman suku bangsa dan agama di negeriku selama 4 kali pertemuan yaitu pertemuan I dengan pemberian pre non-test, pertemuaan II dan III pemberian perlakuan/treatment berupa penggunaan media permainan kartu kuartet, dan post no-test dilakukan pada saat pertemuaan IV. Observasi dilakukan dengan mengamati keterlaksanaan proses pembelajaran dengan menggunakan media permainan kartu kuartet. Berikut dapat dilihat tabel hasil observasi keterlaksanaan media permainan kartu kuartet sebagai berikut:

Tabel 3. Hasil Observasi Keterlaksanaan Pembelajaran IPS dengan Menggunakan Media Permainan Kartu Kuartet

\begin{tabular}{ccc}
\hline & Treatment 1 & Treatment 2 \\
\hline Skor perolehan/ skor maskimal & $21 / 30$ & $25 / 30$ \\
\hline Presentase & $70 \%$ & $83,3 \%$ \\
\hline Kategori & Baik & Sangat Baik \\
\hline
\end{tabular}

Berdasarkan tabel 4.1 keterlaksanaan proses pembelajaran pada pemberian treatmen 1 mencapai presentase sebesar $70 \%$ yang berada pada kategori baik. Adapun untuk keterlaksanaan proses pembelajaran pada pemberiantreatmen 2 mencapai presentase sebesar 
$83,33 \%$ yang berada pada kategori sangat baik. Data tersebut menunjukkan bahwa pelaksanaan pembelajaran dengan menggunakan media permainan kartu kuartet pada pertemuan pertama masih ada langkah-langkah penggunaan media yang belum terlaksana dengan baik dan pada pertemuan kedua ada peningkatan dari pertemuan sebelumnya yaitu semua tahapan-tahapan dalam media permainan kartu kuartet sudah terlaksana sehingga proses pembelajaran dengan menggunakan media permainan kartu kuartet ini berlangsung dengan kategori sangat baik.

\section{b. Gambaran Minat Belajar IPS Siswa Kelas IV SDN 17 Langnga-Langnga}

Pre non-test minat belajar siswa pada kelas eksprimen dilakukan pada hari Kamis tanggal 17 Juni 2021 dengan jumlah subjek penelitian sebanyak 27 orang.

Minat belajar IPS siswa dikategorikan ke dalam 4 indikator yaitu perasaan senang, ketertarikan siswa, dan perhatian siswa. Perasaan siswa dalam mengikuti pembelajaran dapat dilihat dari segi merasa senang saat belajar, belajar tanpa paksaan, serta merasa penasaran jika tidak mengikuti pelajaran. Keterlibatan siswa dalam proses pembelajaran dilihat dari segi kesadaran siswa tentang belajar, aktif dalam proses pembelajaran, bertanya pada guru jika tidak memahami pelajaran yang dipelajari. Perhatian siswa dalam mengikuti pembelajaran dilihat dari segi siswa memperhatikan dan melaksanakan arahan dari guru. Sedangkan ketertarikan siswa mengikuti pembelajaran dilihat dari segi tertariknya siswa mengikuti proses pembelajaran, dan tertarik untuk mengerjakan tugas yang diberikan. Distribusi frekuensi hasil pre non-test minat belajar siswa kelas eksprimen dan kontrol dapat dilihat pada tabel berikut:

Tabel 4. Distribusi dan Persentasi Skor Nilai Pre Non-Test Siswa pada Kelas Eksprimen dan Kontrol terhadap Minat Belajar IPS Siswa

\begin{tabular}{|l|c|c|c|c|c|}
\hline \multirow{2}{*}{ No } & \multirow{2}{*}{ Indikator } & \multicolumn{3}{|c|}{ Frekuensi } & \multicolumn{2}{l|}{ Presentase } \\
\cline { 3 - 6 } & & Eksprimen & Kontrol & Eksprimen & Kontrol \\
\hline $\mathbf{1}$ & Perasaan Senang Siswa & 26 & 19 & $28 \%$ & $27 \%$ \\
\hline $\mathbf{2}$ & Keterlibatan Siswa & 20 & 15 & $22 \%$ & $22 \%$ \\
\hline $\mathbf{3}$ & Perhatian Siswa & 15 & 12 & $16 \%$ & $17 \%$ \\
\hline $\mathbf{4}$ & Ketertarikan Siswa & 31 & 24 & $34 \%$ & $35 \%$ \\
\hline & Jumlah & 92 & 75 & $100 \%$ & $100 \%$ \\
\hline
\end{tabular}

Berdasarkan tabel 4.2 pada kelas eksprimen dapat dilihat frekuensi indikator perasaan senang siswa sebesar 26 dengan presentase $28 \%$, frekuensi indikator keterlibatan siswa sebesar 20 dengan presentase $22 \%$, frekuensi indikator ketertarikan siswa sebesar 15 dengan presentase $16 \%$ dan frekuensi indikator ketertarikan siswa sebesar 31 dengan presentase 34\%. Sedangkan pada kelas kontrol dapat dilihat frekuensi indikator perasaan senang siswa sebesar 19 dengan presentase $27 \%$, frekuensi indikator keterlibatan siswa sebesar 15 dengan presentase $22 \%$, frekuensi indikator ketertarikan siswa sebesar 12 dengan presentase $17 \%$ dan frekuensi indikator ketertarikan siswa sebesar 24 dengan presentase 35\%.Diagram batang pre non-test siswa pada kelas eksprimen dan kontrol terhadap indikator minat belajar IPS siswa. 
Vol. 1 No. 3 Desember 2021, e-ISSN : 2797-8842 | p-ISSN : 2797-9431

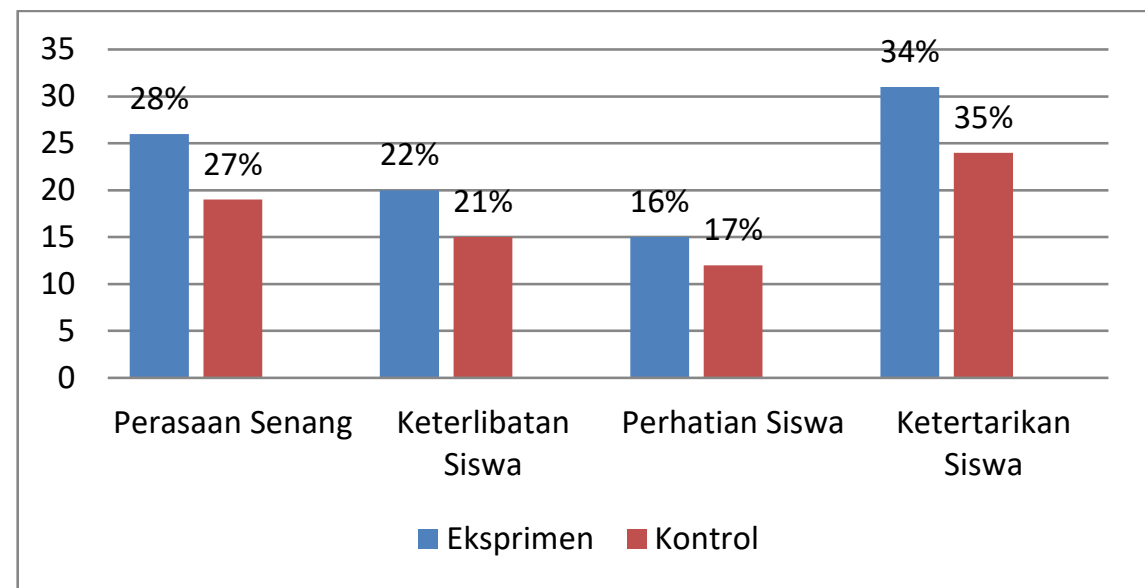

Gambar 1. Diagram batang pre non-test siswa pada kelas eksprimen dan kontrol terhadap indikator minat belajar IPS siswa

Selanjutnya, Data dan Presentasi Skor Nilai Post Non-Test Siswa pada Kelas Eksprimen dan Kontrol terhadap Indikator Minat Belajar IPS Siswa dapat dilihat pada tabel berikut:

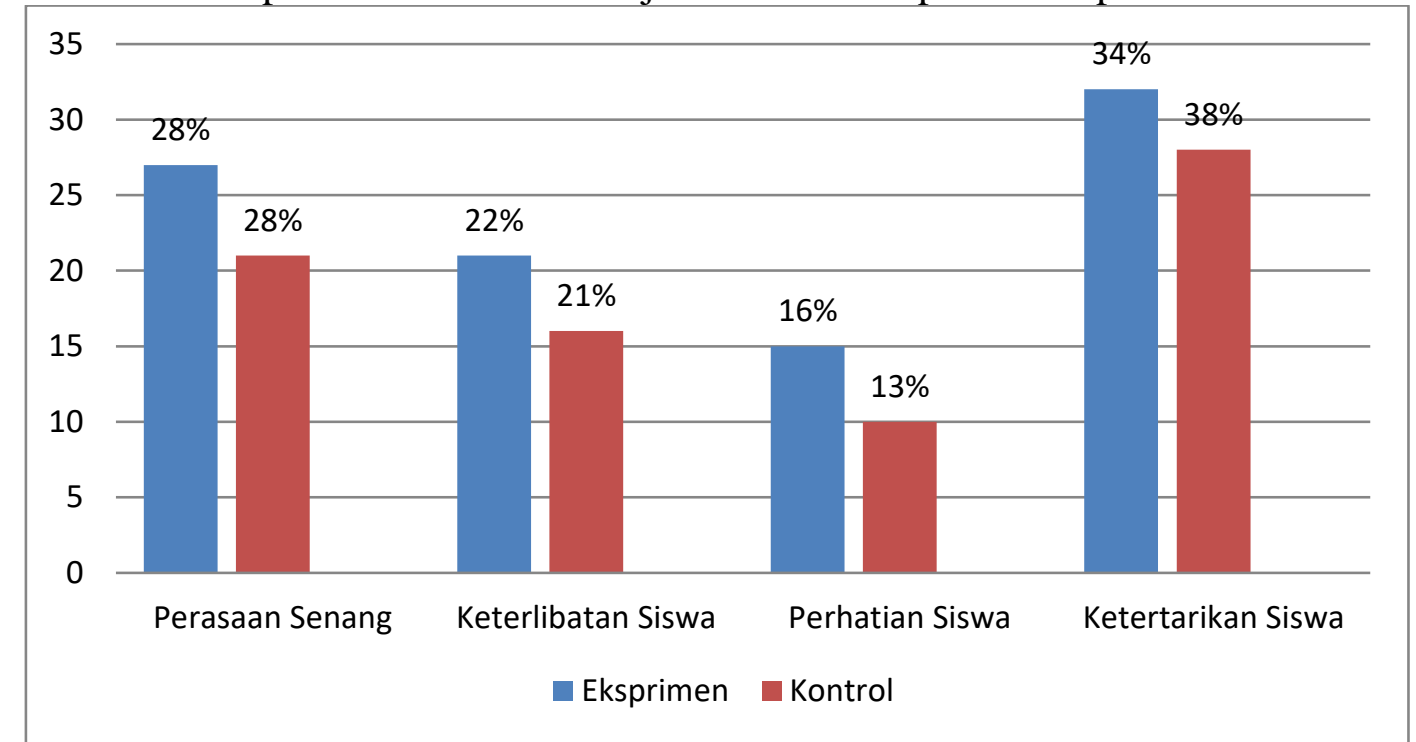

Gambar 2. Diagram batang pre non-test siswa pada kelas eksprimen dan kontrol terhadap indikator minat belajar IPS siswa

\section{Analisis Statistik Inferensial}

Analisis ini dilakukan dengan menguji hasil pre non-test kelas eksprimen dan pre non-test kelas kontrol . Syarat data dikatakan signifikan apabila nilai probalitas lebih besar dari 0,05. Berikut ini adalah hasil Independet Sample t-text pre non-test kelas eksprimen dan pre non-test kelas kontrol.

Tabel 5. Independet Sample T-Test Pre Non-Test Eksprimen dan Pre Non- Test Kontrol

\begin{tabular}{lllll}
\hline Data & T & Df & $\begin{array}{l}\text { Nilai } \\
\text { probalitas }\end{array}$ & Keterangan \\
\hline $\begin{array}{l}\text { Pre Non-Test Kelas Eksprimen } \\
\text { dan Pre Non-TestKelas Kontrol }\end{array}$ & 0,832 & 51 & 0,409 & $\begin{array}{l}0,409<0,05= \\
\text { tidak ada } \\
\text { perbedaan }\end{array}$ \\
\hline
\end{tabular}

Sumber: IBM SPSS Statistic Version 20

Berdasarkan tabel di atas, dapat dilihat bahwa nilai probalitas lebih besar dari 0,05. Hal ini menunjukkan bahwa tidak terdapat perbedaan yang signifikan dari minat belajar antara kelas eksprimen dan kelas kontrol sebelum diberikan perlakuan. Jika nilai t hitung sebesar 0,832 
dibandingkan dengan nilai t tabel dengan nilai $\alpha=5 \%$ dan $\mathrm{df}=51$, diperoleh nilai tabel sebesar 2,007. Maka $t$ hitung memiliki nilai lebih kecil dari $t$ tabel $(0,832<2,007)$. Jika $t$ hitung < $t$ tabel maka dapat disimpulkan bahwa tidak terdapat perbedaan secara signifikan.

\section{Independent sample t-test post non-test kelas eksprimen dan post non-test kelas kontrol}

Analisis ini bertujuan untuk mengetahui perbedaan minat belajar siswa antara kelas yang mengikuti pembelajaran dengan menggunakan media permainan kartu kuartet dan kelas yang yang mengikuti pembelajaran tanpa menggunakan media permainan kartu kuartet. Analisis ini dilakukan dengan menguji hasil post non-test kelas eksprimen dan post non-test kelas kontrol. Syarat data dikatakan ada perbedaan apabila nilai probalitas lebih kecil dari 0,05. Berikut ini adalah hasil Independet Sampel T-Test nilai post non-test kelas eksprimen dan post non-test kelas kontrol.

\begin{tabular}{l} 
Tabel 6. Independet Sample T-Test Post Non-Test \\
\begin{tabular}{lllll}
\hline Data & T & Df & $\begin{array}{l}\text { Nilai } \\
\text { probalitas }\end{array}$ & Keterangan \\
\hline $\begin{array}{l}\text { Post Non-Test Kelas Eksprimen } \\
\text { dan Post Non-Test Kelas Kontrol }\end{array}$ & 3,610 & 51 & 0,001 & $0,001<0,05=$ \\
ada perbedaan
\end{tabular} \\
\hline
\end{tabular}

Sumber: IBM SPSS Statistic Version 20

Berdasarkan tabel tersebut, terlihat bahwa nilai probalitas lebih kecil dari 0,05 berarti Ho ditolak dan Ha diterima. Jika nilai thitung $>\mathrm{t}$-tabel dibandingkan maka terdapat perbedaan yang signifikan. Dari tabel 4.5 diperoleh t-hitung sebesar 3,610 dan nilai t-tabel sebesar 2,007 dengan tingkat signifikan 0,05 df sebesar 51. Hal ini berarti bahwa t-hitung > ttabel $(3,610>2,007)$, maka dapat disimpulkan bahwa terdapat pengaruh penggunaan media permainan kartu kuartet terhadap minat belajar IPS siswa kelas IV SDN 17 Langnga-Langnga.

\section{Pembahasan}

Berdasarkan hasil pengamatan yang dilakukan pada pertemuan pertama, proses pelaksanaan pembelajaran dengan menggunakan media permainan kartu kuartet masih ada beberapa hal yang belum terlaksana dengan presentase keterlaksanaan penggunaan media permainan kartu kuartet dengan kategori baik dikarenakan berdasarkan lembar observasi keterlakasanaan media permaian kartu kuartet pada karena beberapa situasi dan kondisi yang kurang mendukung diantaranya masih banyak siswa yang ribut dan ada beberapa kartu yang rusak. Sebagaimana kekurangan media permainan kartu kuartet yang dikemukakan oleh (Edwita, 2020: 16) adalah "(1) mudah rusak, (2) hanya berbentuk visual dan (3) tidak memiliki audio".Namun selain, mengalami kendala dalam proses pembelajaran menggunakan media permainan kartu juga memiliki keunggulan yaitu siswa sangat antusias dan aktif mengikuti pembelajaran. Hal ini sesuai dengan pendapat Kamil (2003) yaitu: (1) praktis karena mudah dibawa kemana-mana dan mudah dimainkan kapan saja; (2) dapat digunakan untuk kelompok besar atau kecil; (3) selain guru, siswa juga dapat aktif untuk ikut dilibatkan di dalam penyajiannya; (4) permainan kartu kuartet dapat meningkatkan kemampuan berbicara dan menyimak siswa,karena terjadi interaksi antar siswa; (5) dan dapat membantu memudahkan guru dalam upaya menumbuhkan minat dan motivasi siswa untuk belajar (Sumargono et al., 2019, h. 245-246).

Minat belajar siswa dikategorikan kedalam 4 aspek yaitu perasaan senang, ketertarikan siswa, perhatian siswa dan keterlibatan siswa. Dalam proses pembelajaran pendidik dituntut agar dapat menciptakan pembelajaran yang dapat menarik minat belajar siswa khususnya pada mata pelajaran IPS. Pada saat proses pembelajaran berlangsung dengan pemberian treatmen di kelas eksprimen siswa antusias mengikuti pembelajaran antusias dalam proses pembelajaran. Perasaan senang dapat dilihat dari segi belajar tanpa paksaan, merasa senang saat belajar, dan perasaan bila tidak mengikuti pelajaran. Keterlibatan siswa dapat dilihat dari segi siswa 
bertanya pada guru bila tidak memahami pelajaran, aktif dalam proses pembelajaran, dan mengerjakan PR atau tugas dengan baik dan mengumpulkan tepat waktu. Perhatian siswa dapat dilihat dari segi mendengarkan dan memperhtikan penjelasan guru, dan mencatat penjelasan guru. Ketertarikan siswa pada mata pelajaran dapat dilihat dari segi tertarik pada bahan pelajaran, tertarik pada guru IPS, dan tertarik untuk mengerjakan soal-soal.

Secara keseluruhan antara kelas eksprimen dan kelas kontrol terjadi perbedaan minat belajar pada masing-masing kelas. Terlihat saat siswa mengikuti pembelajaran pada setiap pertemuan yang dilakukan dan hasil pengisian angket yang telah diisi oleh siswa. Hasil pengisian angket pada kelas eksprimen yang diberikan perlakuan menggunakan media permainan kartu kuartet menunjukkan adanya minat belajar IPS siswa dibandingkan dengan kelas kontrol tanpa adanya perlakuan yang diberikan saat pembelajaran berlangsung. Adapun nilai pre non-test kelas eksprimen berada pada kategori berminat dan nilai pre non test kelas kontrol berada pada kategori berminat. Sedangkan nilai post non-test kelas eksprimen berada pada kategori sangat berminat dan nilai post non-test kelas kontrol berada pada kategori berminat.

Berdasarkan tabel distribusi dan presentase skor nilai pre non-test dan post non-test pada kelas eksprimen dan kontrol terhadap minat belajar IPS siswa dapat disimpulkan bahwa dari 4 indikator minat belajar yaitu perasaan senang siswa, keterlibatan siswa, perhatian siswa dan ketertarikan siswa yang paling terpengaruhi pada saat penggunaan media permainan kartu kuartet adalah indikator ketertarikan siswa.

Berdasarkan uji hipotesis dengan statistik inferensial menunjukkan bahwa terdapat pengaruh yang signifikan terhadap minat belajar siswa setelah penggunaan media permainan kartu kuartet pada proses pembelajaran. Hal pengujian hipotesis dilakukan dengan dua cara yaitu membandingkan t-hitung serta membandingkan nilai probalitas. Hasil statistik menggunakan perhitungan manual untuk uji t independent sample yang dipadukan dengan bantuan program SPSS 20 diperoleh hasil bahwa Ho ditolak dan Ha diterima. Sedangkan dengan cara membandingkan nilai probalitas, diperoleh nilai signifikansi hasil angket post nontest kelas eksprimen dan kelas kontrol, nilai probalitas 0,001 <0,05 berarti Ho ditolak dan $\mathrm{Ha}$ diterima. Jadi dapat disimpulkan bahwa terdapat pengaruh penggunaan media permainan kartu kuartet terhadap minat belajar IPS siswa kelas IV SDN 17 Langnga-Langnga Kabupaten Pangkajene dan Kepulauan. Hal tersebut sejalan dengan pendapat Meiliani, (2017, h. 50) bahwa salah satu media pembelajaran yang dapat berpengaruh dalam minat belajar siswa dalam proses pembelajaran adalah media permainan kartu kuartet. Demikian pula hasil penelitian yang relevan dilakukan oleh Hidayat, M. (2016) menyatakan bahwa penggunaan media kartu kuartet berpengaruh terhadap minat belajar siswa. Hal ini karena media tersebut mudah digunakan oleh siswa, menyenangkan dan dapat meningkatkan motivasi belajar siswa Sekolah Dasar . Selain itu menurut penelitian yang dilakukan oleh Izzani Sari (2016) menyatakan bahwa pembelajaran dengan media visual menarik minat dan perhatian siswa khususnya oleh siswa SD karena pada jenjang pendidikan SD siswa masih membutuhkan bukti konkret dalam pembelajaran.

\section{KESIMPULAN}

Berdasarkan hasil penelitian yang dilakukan dapat disimpulkan bahwa:

Penggunaan media permaian kartu kuartet pada pembelajaran IPS di kelas IV SDN 17 Langnga-Langnga Kabupaten Pangkajene dan Kepulauan di kelas eksprimen berlangsung dengan sangat baik. Hal ini dapat dilihat dari keterlaksanaan penggunaan media permainan kartu kuartet selam 2 kali petemuan yaitu pada pemberian treatment 1 sebesar dengan kategori baik dan pemberian treatment 2 sebesar dengan kategori sangat baik.

Minat belajar siswa berdasarksan angket yang telah dilakukan bahwa pada kelas eksprimen nilai angket berada pada kategori sangat berminat sedangkan pada kelas kontrol nilai angket berada pada kategori berminat dan dari 4 indikator pada minat belajar yang paling berpengaruh pada saat penggunaan media permainan kartu kuartet adalah indikator ketertarikan siswa. 
Penggunaan media permainan kartu kuartet berpengaruh terhadap minat belajar siswa pada pembelajaran IPS di kelas IV SDN 17 Langnga-Langnga Kabupaten Pangkajene dan Kepulauan .Hal tersebut dikarenakan media kartu permainan kuartet mudah digunakan oleh siswa, menyenangkan dan dapat meningkatkan minat belajar siswa Sekolah Dasar .

\section{DAFTAR PUSTAKA}

Berutu, M. H. A., \& Tambunan, M. I. H. (2018). Pengaruh Minat Dan Kebiasaan Belajar Terhadap Hasil Belajar Biologi Siswa Sma Se-Kota Stabat. Jurnal Biolokus, 1(2), 109.

Guslinda dan Rita Kurnia. (2018). Media Pembelajaran Anak Usia Dini. Surabaya: CV.Jakad Publishing.

Hasanah, U. (2019). Penggunaan Alat Pe rmainan Edukatif (Ape) Pada Taman Kanak-Kanak Se-Kota Metro. AWLADY : Jurnal Pendidikan Anak, 5(1), 20.

Hendra (2017). Pengaruh Penerapan Media Video Pembelajaran Terhadap Minat Belajar Bahasa Indonesia pada Siswa Kelas V SDN Lariang Bangi III Kecamatan Makassar Kota Makassar. Makassar: Prodi Pendidikan Guru Sekolah Dasar Fakultas Ilmu Pendidikan Universitas Negeri Makassar.

Hidayat, M. (2016). Pengaruh Penerapana Media Pembelajaran Kartu Kuartet terhadap Minat Belajar Siswa pada Mata Pelajaran IPA Kelas IV SD Inpres BTN IKIP 1 Kecamatan Rappocini Kota Makassar: Program Studi Pendidikan Guru Sekolah Dasar Fakultas Ilmu Pendidikan Universitas Negeri Makassar.

Khodijah, S. S., \& Setiawan, W. (2020). Analisis Minat Belajar Matematika Siswa Smp Kelas

Ix Pada Materi Grafik Fungsi Kuadrat Berbantuan Software Geogebra. Journal of Honai Math, 3(1), 27-40.

Kurniati. (2016). Permainan Tradisional dan Perannyadalam Mengembangkan Keterampilan Sosial Anak. Jakarta: Prenada media Group.

Nasution, Awal Kurnia Putra. (2019). Media Pembelajaran Berbasi Internet. Aceh: As-Salam Press.

Pane, A., \& Darwis Dasopang, M. (2017). Belajar Dan Pembelajaran. FITRAH:Jurnal Kajian Ilmu-Ilmu Keislaman, 3(2), 333.

Rusniati. (2017). Pengaruh Minat Belajar Terhadap Prestasi Belajar Bidang Studi Ekonomi Siswa Ma Al Fattah Sumbermulyo. Jurnal Ilmiah Pendidikan Dan Ekonomi, 1(1), 21 36.

Sadiman et.al., (2018). Media Pendidikan: Pengertian, Pengembangan, dan Pemanfaatannya. Depok: Pustekom dan PT Raja Grafindo Persada.

Sari, N. N., \& Miaz, Y. (2019). Penggunaan media peta berbasis multimedia. 3(3), 929-934.

Satriawati. (2018). Media dan Sumber Belajar. Yogyakarta: Grup Penerbitan CV Budi Utama. Setiawati, E., Desri, M., \& Solihatulmilah, E. (2019). Permainan Ular Tangga Dalam Mengingkatkan Kemampuan Moral Anak. Jurnal Petik, 5(1), 85-91.

Sirait, E. D. (2016). Pengaruh Minat Belajar Terhadap Prestasi Belajar Matematika. Formatif: Jurnal Ilmiah Pendidikan MIPA, 6(1), 35-43.

Siska. (2016). Konsep Dasar IPS. Yogyakarta: Garudhawaca.

Sumargono, S., Lisnawati, L., Rohmayani, S., \& Masdi, M. (2019). Kartu Kuartet Boelang (Boedaya Lampung) Sebagai Media Edukasi Boedaya Lokal Di Smpn Bandarlampung. HISTORIA : Jurnal Program Studi Pendidikan Sejarah, 7(2), 243.

Sumarno. (2017). Hard Skills dan Soft Skills Matematika Siswa. Bandung: Aditama.

Susanto, A. (2016). Teori Belajar dan Pembelajaran di Sekolah Dasar. Jakarta: Kencana. Widagdo, A. (2020). Pengembangan Media Kartu Kuartet Berbasis Tai Pada Muatan Ips. Jurnal Kreatif: Jurnal Kependidikan Dasar, 10(2), 182-189. 